\title{
Sustainable livelihoods through conservation of wetland resources: a case of economic benefits from Ghodaghodi Lake, western Nepal
}

\author{
Pramod Lamsal, Krishna Prasad Pant ${ }^{1}$, Lalit Kumar ${ }^{2}$ and Kishor Atreya ${ }^{1}$
}

\begin{abstract}
We investigated the participation of local ethnic groups in wetland conservation, determined the economic benefits that they received from the wetlands, and assessed socioeconomic factors that affect dependency on wetlands. A total of 217 wetland resource-user households residing around Ghodaghodi Lake, western Nepal were surveyed. Data were analyzed using descriptive statistics, t-tests and ordinary least squares regressions. The wetland resources contributed significantly to the household economy of the local people. Each household extracted lake resources at an annual worth of NPR 4379 (\$63 USD), equivalent to $12.4 \%$ of the household total gross income. Although the people maintained a positive attitude toward wetland conservation, their participation in conservation efforts was inadequate. Socioeconomic factors such as larger household size, older age of the head of the family, and larger area of agricultural land increased the rate of resource extraction. In contrast, when households were involved with local conservation organizations, resource extraction was reduced. We recommend the following resource conservation and livelihood strategies: implementation of community-based conservation approaches to increase system productivity, adoption of biogas plants, and improved cooking stoves to reduce fuelwood consumption, coupled with conservation awareness programs.
\end{abstract}

Key Words: conservation attitude; conservation participation; livelihood; sustainability; wetland conservation

\section{INTRODUCTION}

Wetland ecosystems are the most diverse and productive ecosystems on Earth and include marshes, lakes, rivers, flood basins, estuarine deltas, ponds, rice fields, and marine water areas where the depth at low tide does not exceed $6 \mathrm{~m}$ (Convention on Wetlands 1971). Wetland ecosystems are important from conservation and sustainable management viewpoints because of their rich diversity of flora and fauna. Tangible and intangible diverse resources and products of wetland functions such as fodder, fishes, fuelwood, nontimber forest products, ecotourism, and flood control have historically provided a source of income and livelihood for human beings. However, population growth and associated anthropogenic interferences have depleted these resources and reduced the rates of flow of the ecosystem services. The loss of wetland ecosystem services damages the health and well-being of individuals and local communities and diminishes their development prospects (Millennium Ecosystem Assessment 2005). This problem is of serious concern in many countries where ethnic communities are highly dependent on wetland resources. The problem is particularly severe in countries that have weak policy and management strategies, negatively affecting the conservation and sustainable management of wetland resources.

\section{Wetlands: a source of livelihood}

It is widely recognized that wetlands provide several ecosystem services that contribute to human well-being. The major ecosystem services that wetlands provide include fish, fiber, water supply, water purification, climate regulation, flood regulation, coastal protection, recreational opportunities, and tourism (Millennium Ecosystem Assessment 2005). The role of wetland resources in the livelihood of the poor is particularly important in developing countries. For example, wetland activities at the Pece Wetland in Uganda provide $>50 \%$ of the monthly income of the dependent population (Opio et al. 2011). Nearly $90 \%$ of the East Godavari Delta population in Andhra Pradesh, India depends completely on mangrove wetland products for sustaining their livelihoods (Dahdouh-Guebas et al. 2006). Bosma et al. (2012) report that livelihood of $40 \%$ of households in Mahakam Delta depends on resources from mangrove wetland ecosystems. In addition, this number is as high as $80 \%$ when pond-farming activities such as fish and shrimp cultivation are included.

However, declining fish resources in the coastal wetland at Nijhum Dwip in Bangladesh have forced fishing communities to consider alternate livelihood measures such as poultry, livestock and crop farming, handicrafts, and nonfarm day labor (Rahman et al. 2012). In many cases, environmental and biodiversity concerns are important for sustaining rural livelihoods. However, protecting wetlands to maintain their pristine state is not always feasible, especially as population pressures increase (Abbot and Hailu 2001). On Nijhum Dwip Island, Iftekhar and Takama (2008) observed high dependence of the increasing population on the mangrove wetland ecosystem for generating substantial income. In addition, the local people perceived this ecosystem as an important local resource for their livelihoods and economic development.

In Nepal, wetland resources play an important role in the livelihoods of ethnic communities. More than 21 ethnic communities have been listed as dependent on wetland resources (IUCN 1998). Some of these communities are the most marginalized and the poorest. Indigenous knowledge of ethnic communities is important for conserving the wetlands and for using wetland resources. At the Koshi Tappu Wetland, Thapa and Dahal (2009) identified the need for increased awareness on the use of wetland resources that are neglected or unused because of a lack of indigenous knowledge about their economic value. Thus, wetlands play a major role in the livelihoods of the local people; however, there is limited empirical research to understand the relationship between wetlands and livelihoods. 


\section{Overexploitation and wetland degradation}

More than $50 \%$ of the world's wetlands have been altered, degraded, or lost in the last 150 years (O'Connell 2003). The main causes of these losses are anthropogenic and include decline in area, changes in water regime and water quality, and introduction of alien species. Excessive exploitation and the resulting degradation of wetland resources have attracted enormous concern from researchers. Xie et al. (2009) reported a loss of wetland habitat from excessive resource use and subsequent degradation in China. In general, the livelihood-generating actions of the poor communities that reside near wetlands, and their dependency on the wetland resources, have degraded wetlands. Thus, a wide range of human activities have altered wetlands around the world and caused their degradation (O'Connell 2003). Wetlands are considered sustainable when they have the ability to cope with and recover from stresses and shocks, which allows them to maintain or improve their capabilities in the future. A necessary condition for conserving these resources is the ability of the local communities to detect, measure, and reverse ecological changes. In Nepal, poor, wetland-dependent communities have limited opportunities to pursue alternative livelihoods, and as a result, even though they realize the implication of their unsustainable use, overharvesting of lake resources remains in practice (Jha 2008). This unsustainable use of wetland resources warrants urgent study.

\section{Institutional enhancement and local participation for resource conservation}

The need for community participation in the conservation and management of wetland resources is understood globally (Williams 2002). The traditional approach of protection by prohibition using legislation and guarding is losing ground. The restriction of local people's access to natural resources that have supported their livelihoods for generations can be good from a conservation point of view only for a short time (Andrade and Rhodes 2012). Andrade and Rhodes (2012) report that the higher the level of community participation, the higher their compliance to the resource conservation; community inclusion is a must for long-term conservation. Legislation, policies, and programs that accommodate local people in the decision-making process make resource conservation cost-effective and sustainable (Pimbert and Pretty, unpublished manuscript: http://pubs.iied.org/pdfs/G01094. pdf).

In developing countries, where food security and poverty reduction receive higher priority than environmental protection, wetland conservation is difficult if the local communities do not understand the value of the wetlands (Wood et al. 2002). For successful conservation and management, the participating local communities should be fully aware of the importance of wetlands as parts of water cycles, as well as the nature and effects of human impacts (Williams 2002). Participation of indigenous communities with their traditional knowledge, skills, and practices can help resource conservation while meeting their daily requirements. For fishing communities in Bangladesh, Rahman and Begum (2011) report the importance of seeking livelihood diversification options that enable the conservation of exploited wetlands without harming the livelihood of dependent resource users. For two wetland communities in the Marituba and Guapore valleys, Brazil, Diegues (1991) found that if the cultural aspects and needs of the local users were met, then it was very likely that full economic use of wetland resources could be achieved along with conservation goals. A study by Chun et al. (2012), at Temiang River watershed in Malaysia, indicates that voluntary involvement was more important than awareness alone for conservation, and factors such as age, education, gender, income level, marital status, and residential location affected participation. Islam (2011) investigated community-based water resource management practices in South Asian countries and recommends using community-centered approaches to identify local vulnerabilities and implement appropriate solutions.

Enhancement of the role of existing institutions is equally important for sustainable resource management. Conservation activities of local conservation organizations are more effective than those of outside designed and induced projects. Communitybased conservation is a better alternative compared to centrallevel handling of natural resources and is an effective tool in solving conflict and engaging community participation for resource conservation, including wetlands (Trisurat 2006). Community-based conservation approaches have been adopted in a few wetlands of Bangladesh for more than a decade and have been highly successful in securing public participation, benefiting sharing and conservation (Thompson and Choudhury 2007). Olsson et al. (2004) note the successful evolution of adaptive comanagement for a wetland ecosystem in southern Sweden and emphasize the social-ecological transformation behind it. The underlying theory is that social and ecological systems are linked and social transformation is the key to reach the capacity to manage ecosystems in a sustainable way so that human well-being is strengthened in the long run.

Several studies have been conducted in Nepal regarding different aspects of wetlands, for example, bathymetry and limnology (Gurung et al. 2009), forest cover change assessment (Khanal 2009), integrated wetland watershed management (Regmi et al. 2009), conservation status (Siwakoti and Karki 2009), water quality parameter and bird status (Thapa and Saund 2012), and limnological status (Niraula 2012). However, very few researchers have studied ethnic participation in resource conservation and the contributions of wetland resources to human livelihoods. Our objectives were to assess community participation in and perception of wetland resource conservation, and to determine the pattern of wetland resource use and its economic contribution to local ethnic communities residing near the Ghodaghodi Lake complex (GLC) in Nepal.

\section{STUDY AREA}

The study was conducted in the GLC, in the Kailali District of western Nepal (2841'03” N, 8056’43” E, $205 \mathrm{~m}$ above mean sea level; Fig. 1). The total area of water bodies is 248 ha and includes nine lakes: Ghodaghodi (138 ha), Nakharodi (70 ha), Bainshwa (10 ha), Budhi Nakharodi (6 ha), Ojhwa (6 ha), Purbi Ojhwa (5 ha), Ramphal (5 ha), Sunpokari (5 ha), and Chatiya (3 ha). Ghodaghodi and Nakharodi lakes are perennial, whereas the others are seasonal. The water sources of the lakes include rainfall, surface flow, springs, and floods from nearby rivers.

The watershed of the GLC includes barren land, mixed sal (Shorea robusta) forest, scrubland, and agricultural land (Sah and Heinen 2001). The watershed comprises agricultural land (60\%), forestland and lakes $(37 \%)$, settlements and roads $(2 \%)$, and rivers and streams (1\%; Bam 2002). The population of the study area 
has been increasing in recent decades. The GLC is surrounded by three Village Development Committees (VDCs), namely Darakh, Sandepani, and Ramsikharjhala. The population of these VDCs was 25,286 with 3442 households in 1991 (CBS 1991) and increased to 43,687 with 6110 households in 2001 (CBS 2001). The recent national population census held in 2011 recorded a population of 60,531 with 10,587 households in the same VDCs (CBS 2011). Thus, in a mere two decades the population has more than doubled, and the number of households has increased threefold. The population is heterogeneous and comprises indigenous (Tharu) and migrant peoples (Pahadias from the hills and other Terai castes).

Fig. 1. Map of Nepal, indicating the location of the Ghodaghodi Lake complex study area (inset).

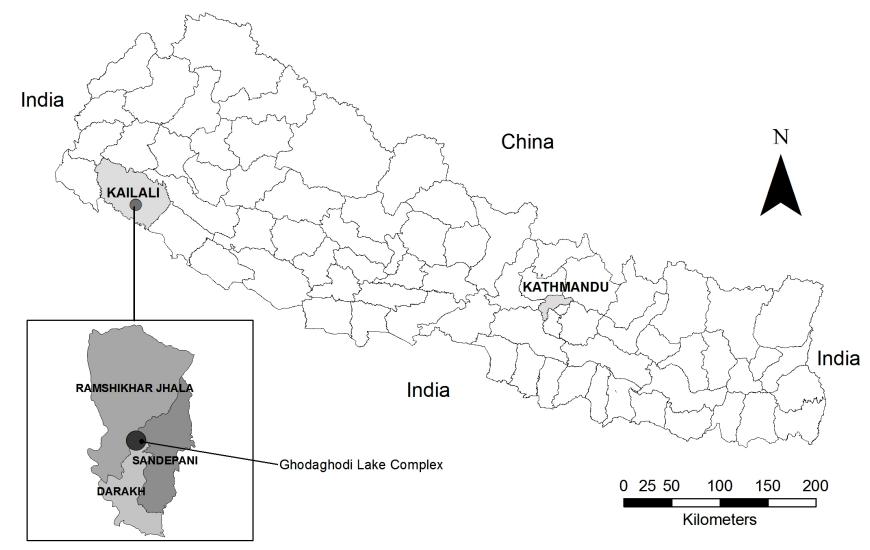

GLC is rich in biodiversity. IUCN (1998) reported 107 aquatic macrophyte, 137 tree, 30 fish, 140 avian, and 34 mammalian species. It also identified some major threats; among those of most concern were illegal harvesting and smuggling of sal (Shorea robusta) and khair (Acacia catechu) and poaching of mammals and birds (IUCN 1998). Illegal hunting of wild boar (Sus scrofa), deer, and other wildlife, as well as bird trapping and egg collection were also prevalent. The excessive growth of aquatic macrophytes such as Ceratophyllum demersum, Nelumbo nucifera, Naja minor, and Hydrilla verticillata from the water surface were evident.

\section{Lake management systems}

Lake management led by a steering committee has been initiated in this lake complex. In August 2003, the Ramsar Convention listed GLC as a Wetland of International Importance (Ramsar Site 1314), citing its rich biological diversity, local livelihood dependence, and possible anthropogenic threats. The lakes are under the authority of the District Forest Office of Kailali, Government of Nepal. The local people have been using the lake resources since ancient times to sustain their livelihoods. Ever since it was designated a Ramsar Site, the GLC conservation and sustainable use have been priority actions for government and local organizations. To facilitate this, the International Union for Conservation of Nature (IUCN) Nepal and the United Nations Development Program (UNDP) have been helping the government and local organizations in the optimal use and management of the lake resources. A lake management steering committee, a type of multi-stakeholder forum, has been formed with the participation of various stakeholders. The stakeholders include representatives from the District Forest Office, the president of the Ghodaghodi Area Conservation and Awareness Forum (a local organization), a teacher of the local school, local VDC-level political leaders, and a representative of the lake resource users. Issues on the lakes are normally discussed in quarterly meetings of the steering committee. An annual conservation management plan is in place (developed by IUCN and UNDP), and the steering committee is responsible for implementing, monitoring, and reporting the progress to the government and donor agencies. The major activities include seedling plantation, an awareness campaign focusing on villagers and visitors, maintenance of visitor infrastructure, and logistic arrangements for religious celebrations of the Tharu community. However, the lake management steering committee has been acting in a top-down approach. Most of the programs are designed at the central level and endorsed and implemented by this steering committee at the local level.

Ghodaghodi Lake is an important religious place, with a shrine dedicated to the Ghodaghodi deity, where indigenous Tharu people celebrate a traditional festival, Agan Panchami, in December and take a holy bath in the lake. Bainshwa Lake has been commercialized by allowing private fishermen to culture and harvest commercial fish for the local fish market. It has been contracted for commercial fish farming (mainly outsiders), and is a major source of income for the committee, apart from some conservation budget from the government and annual voluntary donations from the lake resource users. The people residing near the lake complex are the main users of its resources.

\section{METHODS}

\section{Study design}

We hypothesized that (1) both indigenous and migrant populations have participated in and perceive positive benefits of the conservation activities, and (2) Ghodaghodi Lake resources contribute significantly to the household economy of the local people, and both indigenous and migrant populations derive equal economic benefits from the GLC. Our study was based on primary data collected from focus group discussions (FGD), household surveys, and key-informant interviews (KII). We organized a local meeting to identify the wards (the smallest administrative unit) in the VDCs nearby the wetland complex. Five participants attended this meeting: three local farmers, a schoolteacher, and the head of a local conservation organization. Three wards near the lake were selected from each sample VDC with the assumption that the majority of those households rely on wetland resources for their livelihoods. Of the 2172 identified households in the nine wards of the three VDCs, $10 \%$ were selected using proportional random sampling (Table 1). This gave us a total of 217 households for the questionnaire survey.

A household survey questionnaire was developed and pre-tested. The questionnaire included modules on ethnic and demographic characteristics, land holding and uses, environmental awareness, conservation participation, lake resource uses and income, resource sustainability trends, and factors affecting wetland income. The questionnaire was translated into the Nepali language to make it more readable by the local enumerators. Intensive field surveys were conducted between April 10 and May 
20, 2007. Before conducting the formal field surveys, three local enumerators, grade 12 educated and residing in the respective VDCs, were selected and trained for three days by the first author. Attempts were made to familiarize enumerators with all questions on the questionnaire to eliminate any confusion. The senior-most members of the households were interviewed. In cases where such members were not available, other members with the best knowledge on the uses of lake resources were interviewed.

Table 1. List of Village Development Committees sampled and corresponding sample sizes.

\begin{tabular}{lcc}
\hline \hline $\begin{array}{l}\text { Village Development } \\
\text { Committee }\end{array}$ & $\begin{array}{c}\text { Total number of } \\
\text { households in three } \\
\text { sample wards } \dagger\end{array}$ & $\begin{array}{c}10 \% \text { of total } \\
\text { number of } \\
\text { households } \ddagger\end{array}$ \\
\hline Darakh & 858 & $86(40 \%)$ \\
Sandepani & 854 & $85(39 \%)$ \\
Ramsikharjhala & 460 & $45(21 \%)$ \\
Total & 2172 & $217(100 \%)$ \\
\hline
\end{tabular}

$\dagger$ Source: CBS (2001).

$\$$ Number of households sampled.

$\mathrm{KII}$ in each of the nine wards and three FGD in each VDC were conducted to obtain supplemental information that could not be obtained during the household survey, for example, existing threats in the complex and the vision of local people for the potential future conservation and development of Ghodaghodi Lake. These KII and FGD also helped us to determine the monetary value of wetland resources to quantify the economic benefit received by the households. The total quantities of lake resources extracted by the individual sampled households were obtained through the questionnaire, for example, weight of fishes and singar in kilograms, value of firewood and fodder as bhari ( $25 \mathrm{~kg}=1 \mathrm{bhari})$, and value of sal leaf as mutha (25-30 leaf pieces = 1 mutha). The resources transacted in the market (fuelwood, fish, singar, and sal leaf) were multiplied by their 12-month average price in the previous year as derived from KII and FGD. For nonmarket goods (fodder), the average shadow prices were determined using a barter game (Adhikari 2003) in which KII and FGD respondents were asked to exchange the fodder with wheat, a product having a well-established local market price.

\section{Data analysis}

For statistical analysis, ethnicity was categorized as indigenous and migrant, providing us with 73 and 144 households belonging to these two categories, respectively.

The wetland resource income (WI) was calculated as:

$$
W I=\sum Q_{i} \times P_{i}
$$

Where $Q_{\mathrm{i}}$ is the average quantity of the resource extracted for the $i$ th resource in a year; $P_{\mathrm{i}}$ is the price per unit of the $i$ th resource; and $i$ is the number of wetland resources (e.g., fuelwood, fodder, fishes, singar, sal leaf).
Qualitative and quantitative data were analyzed using correlation and regression analyses in SPSS 11.5 (SPSS Inc., Chicago, Illinois, USA). Two-sample $t$-tests were used to compare the wetland resource incomes to the household economies. The socioeconomic factors that affected WI were determined using ordinary least squares (OLS) regression.

The explanatory variables included in OLS regression were household size (HHS), education of the respondent (EDU), outstay from the house for more than six months (OHSM), the walking distance from the sampled household to the lake (DIST), whether a household member worked for a wetland-related organization (WORK), the age of the respondent (AGE), and the total agricultural land area (LAND) of the sampled household in kattha $\left(1 \mathrm{kattha}=333 \mathrm{~m}^{2}\right)$. The explanatory variables and their hypothesized direction of influence are listed in Table 2. The model was specified as:

$$
\begin{aligned}
W I= & \alpha+\beta_{1} H H S+\beta_{2} E D U+\beta_{3} O H S M+\beta_{4} D I S T \\
& +\beta_{5} W O R K+\beta_{6} A G E+\beta_{7} L A N D+\varepsilon
\end{aligned}
$$

Where $\varepsilon$ is an error term, and $\alpha$ and $\beta_{i}$ are estimated parameters.

We assumed that all of the listed socioeconomic variables affected the WI of individual households. The greater the number of members in the household (HHS), the more the resource extraction and the higher the income would be from selling wetland resources. A higher level of education (EDU) was thought to be negative to wetland incomes because well-educated individuals were likely to have alternative employment and good knowledge of the negative effects of resource extraction on biodiversity and hence would be less likely to collect such lake resources, resulting in lower incomes. Many household members, especially young and older men, are breadwinners of the family in the study area and migrate seasonally to the neighboring countries in search of employment. We assume lower resource extraction in households where such members left for jobs and were absent for more than six months (OHSM). Walking distance to and from the lake (DIST) is believed to be an important factor for people in extracting resources. The higher the walking distance, the lower the frequency of visits, and thus, the lower the resource extraction.

The involvement of people with the local conservation organization (WORK) means that they are more aware of the negative consequences of resource exploitation in the lake ecosystem. We are of the view that if a single member of a household is involved with such an organization, then he/she would be more environmentally aware and would motivate other members of the household on the importance of conservation and sustainable resource use, ultimately leading to less lake resource extraction. The higher the age (AGE), the greater would be the experience in methods and seasons of wetland resource extraction, and the greater the income. We postulated that the households that have older members would have more resource extraction and consequently more income than those of households with younger members. We assume that households that have more agricultural land (LAND) have diversified income sources and rarely go for lake resource extraction; therefore, they would have lower income from wetland resources. 
Table 2. Explanatory variables, associated hypothesis for direction of the relation with lake resource use, and descriptive statistics.

\begin{tabular}{|c|c|c|c|c|c|c|}
\hline Variable & Description & $\begin{array}{c}\text { Direction of } \\
\text { hypothesis }\end{array}$ & Minimum & Maximum & Mean & $\begin{array}{l}\text { Standard } \\
\text { deviation }\end{array}$ \\
\hline$\overline{\mathrm{HHS}}$ & Household size & + & 1 & 35 & 6.18 & 3.034 \\
\hline EDU & Education level & - & 1 & 5 & 2.17 & 1.084 \\
\hline OHSM & $\begin{array}{l}\text { Outstay of the head of household from home for }> \\
6 \text { mo }\end{array}$ & - & 0 & 1 & 0.28 & 0.448 \\
\hline DIST & $\begin{array}{l}\text { Walking distance to the lake from the household } \\
\text { (one way in minutes) }\end{array}$ & - & 5 & 110 & 34.85 & 21.400 \\
\hline WORK & $\begin{array}{l}\text { Household member(s) work for a wetland related } \\
\text { organization }\end{array}$ & - & 0 & 1 & 0.16 & 0.369 \\
\hline AGE & Age of the respondent & + & 17 & 69 & 35.95 & 11.539 \\
\hline LAND & $\begin{array}{l}\text { Agricultural land belonging to the household } \\
\text { (kattha†) }\end{array}$ & - & 1 & 80 & 17.71 & 16.343 \\
\hline
\end{tabular}

$\dagger 1$ kattha $=333 \mathrm{~m}^{2}$.

\section{RESULTS AND DISCUSSION}

\section{Perceptions and attitudes toward participation in wetland} conservation

Our results show a low level of participation by local communities in the conservation and awareness program. Approximately $18 \%$ of the sampled households were involved in local conservation and awareness programs (e.g., meetings, workshops, training, seedling plantation, and clean-up).

A total of 15 local organizations were working in the study area with one thematic issue as Ghodaghodi Lake conservation. We attempted to determine the perceptions of people toward these local organizations. Thus, we categorized the conservation activities of the organizations as good, very good, or excellent and allowed respondents to choose a rating. The majority of the sampled households (69\% of migrant and $63 \%$ of indigenous households) rated the conservation activities as good, while $28 \%$ and $36 \%$ of migrant and indigenous respondents, respectively, rated the conservation activities as very good. The local community welcomed the conservation organizations only if they saw a long-term benefit and local participation. This necessitates conservation organizations to provide pro-community programs so that additional households come forward and lend a hand for the participation and conservation programs. Apart from this, involvement of local people in the planning and decision-making processes of the lake user group steering committee could increase people's participation and alter their perceptions toward the development organizations. Baral and Heinen (2007) and Diouf (2002) support the view that decentralized participatory conservation programs could help resource-dependent developing countries minimize obstacles between conservation and sustainable development if they are implemented carefully.

Attempts were made to determine the respondents' attitudes and perceptions of changes that were brought to the community by the steering-committee-led conservation model. Four choices were given: strongly agree, agree, disagree, and strongly disagree. This model provided individuals more access to resource use. Approximately two-thirds (65\%) of the respondents agreed that the current model provided more access for all sections of the community to the lake complex. The same percentage of households disagreed that rules and regulations had been imposed on the people for entering and using lake resources. Approximately two-thirds (64\%) agreed that compared to the past, lake resources at the time of our study fulfilled the family food and monetary demand, while approximately $46 \%$ were not convinced that the changes brought about by changes in the management system had helped in the reduction of poverty. Likewise, $71 \%$ believed that women and lower-caste people were at the forefront of lake conservation activities.

In developing countries, people that depend on the natural resources, including wetlands, come forward for conservation action once they realize the economic value of that ecosystem to their family's subsistence. Their attitudes and perceptions, in many cases, are shaped by the benefits that are seen to accrue from such ecosystem resources. In our study, although the participation of local people was low, the majority of them were found to have a positive view of the conservation activities and community-led conservation model of local organizations. The positive attitudes and perceptions are a good indicator that if some conservation initiative is taken, for example, a community-based conservation approach, there is a greater possibility of increased participation of local people in the conservation activities. However, the current conservation approach has limited community participation in decision making and planning. A number of previous studies (Mehta and Heinen 2001, Andrianandrasana et al. 2005, Bajracharya et al. 2006) also propose a community-based conservation approach for better wetland resource use and conservation. The implementation of community forest programs, which also incorporate the community-based conservation approach along with many other pro-poor aspects (equal access and equitable resource distribution) in the lake complex, can be a good option because they empower the poor and disadvantaged resource-dependent communities and improve their livelihoods in the long run. During the FGD, the local people residing near the GLC also revealed the need for a community forest regime to further strengthen the current management practices.

\section{Lake resource extraction and degradation}

The wetland resources that local people collect at present are fuelwood, fodder, fish, singar (Trapa quadrispinosa), and sal leaf (Shorea robusta; Fig. 2). 
Fig. 2. Percentage of households extracting various resources from Ghodaghodi Lake complex, Nepal.

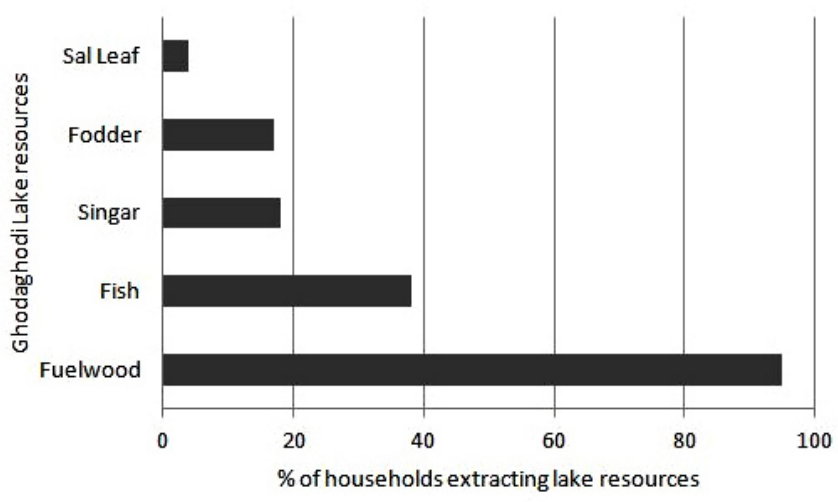

Fuelwood was found to be the most extracted wetland resource by the local ethnic communities at GLC. Approximately $95 \%$ of households collected fuelwood from the lake complex as a source of cooking energy. In addition, $38 \%$ collected fish for food, and singar was another important resource for the indigenous community. In addition, nearly $18 \%$ of the households relied on the lake to fulfill their need for livestock fodder. Other wetland resources that were collected in small quantities include sal leaf. We found that both ethnic groups depended on the resources of Ghodaghodi Lake, especially fuelwood, and this finding is supported by the findings of Sah and Heinen (2001).

During FGD, a majority of the participants raised concerns about the degradation of the lake ecosystem from excessive resource extraction. Habitat destruction, as a result of cutting trees and shrubs from the lake complex, reduced the habitat for larger animals. Large mammals such as tiger (Panthera tigris), sloth bear (Melursus ursinus), as well as most of the deer species, have not been seen in the area for a couple of years. Local and migratory bird species are also in a declining state, and this information has been verified by an analysis of resource sustainability trends. The current population pressure and increased settlements, fragmentation and thinning of the forest, and expansion of agricultural land are the major factors contributing to habitat degradation.

\section{Lake resources and household economy}

Our survey indicates that nearly $65 \%$ of households have adopted agriculture, followed by migratory labor work to India ( $8 \%$ ), as well as small businesses, school teaching, and other types of jobs. One-third of sampled households had food sufficient for more than one year. This means that the other $67 \%$ of households depended on Ghodaghodi Lake either for their own consumption or for the sale of such resources to obtain money for food. Turyahabwe et al. (2013) found that $>80 \%$ of the population living near the wetlands in Uganda depend on lake resources for maintaining household food security and livelihoods. Halima and Munishi (2009) found that $94 \%$ of local people residing around Nyumba Ya Mungu Wetland in northern Tanzania depend on its resources to supplement their income and food. Overall, we found that each local household extracted wetland resources with an annual economic value of NPR 4379 (\$63 USD; range: NPR 690
[\$9.86 USD] to 19,200 [\$274 USD]; Table 3). The total gross income for each household (mean \pm SD) calculated for the sampled households was NPR 35,193 \pm 30,458 (\$503 $\pm \$ 435$ USD). The economic value of wetland resources that a household collects was equivalent to $12.4 \%$ of the total gross income. Studies of the economic contribution of wetland resource extraction are limited for Nepal, but this figure can be compared with the findings of studies of community forestry in Nepal. Chhetri (2005) reported an average contribution of $7.4 \%$ of the total household income of local people from the community forest. Kafle (2008) reported contributions from the community forest ranging from $2 \%$ to $12 \%$ for households from different income strata. Adhikari (2003) reported a 4-8\% contribution of community forestry to the net income of households in the midhills region of Nepal. Nearly $59 \%$ of the indigenous households and $75 \%$ of the migrant households extracted resources from the wetlands that were worth NPR $<5,000$ ( $<\$ 71$ USD). Approximately $37 \%$ of the indigenous households and $23 \%$ of the migrant households received income from lake resources of between NPR 5000 (\$71 USD) and NPR 10,000 (\$142 USD). The remaining households (4\% indigenous and $2 \%$ migrants) had an income of between NPR 10,000 (\$142 USD) and 15,000 (\$214 USD) from the wetland.

Table 3. Monetary value of lake resources extracted by the sampled households $\dagger$.

\begin{tabular}{lcccc}
\hline \hline $\begin{array}{l}\text { Lake resource (unit of } \\
\text { measure) }\end{array}$ & $\begin{array}{c}\text { Quantity } \\
\text { harvested } \\
\text { (households/ } \\
\text { yr) }\end{array}$ & $\begin{array}{c}\text { Unit } \\
\text { valuet }\end{array}$ & $\begin{array}{c}\text { Mean } \\
\text { valuet }\end{array}$ & $\begin{array}{c}\text { Standard } \\
\text { deviation }\end{array}$ \\
\hline Fuelwood (bhari) & 84.6 & 40 & 3384.1 & 1712.91 \\
Fodder (bhari) & 7 & 20 & 140.4 & 343.03 \\
Fish (kg) & 7.41 & 100 & 741.0 & 1174.82 \\
Trapa quadrispinosal & 3.88 & 25 & 97.1 & 256.95 \\
Singar (kg) & 1.6 & 10 & 16.0 & 84.42 \\
$\begin{array}{l}\text { Sal leaf (mutha) } \\
\text { Total }\end{array}$ & & & 4378.6 & \\
\hline
\end{tabular}

$\dagger$ Total number of sampled households $=217$.

$\$ N P R$. At the time of the survey, the exchange rate was USD $\$ 1=$ NPR 70.

Statistical analyses showed that the wetland resources (fuelwood, fodder, fish, singar, and sal leaf) contributed significantly to the household economy: the mean income of households from wetland resources was significantly different from zero. If we extract information by ethnic group, then indigenous households gained significantly more economic benefit annually (NPR 4978 or \$71 USD) than did migrant households (NPR 4074 or $\$ 58$ USD). This shows the economic contribution of Ghodaghodi Lake resources to the local users.

A similar contribution of wetland fishing was found in the fishing community of Nijhum Dwip in Bangladesh (Rahman et al. 2012). In that case, $46 \%$ of the population was found to earn between $\$ 625 / \mathrm{yr}$ and $\$ 937 / \mathrm{yr}$ (USD). Adekola et al. (2012) found that the Ga Mampa wetland of South Africa contributed to the livelihood of the local community with an annual net value of \$211/ household, which was much greater than the annual cash income 
Table 4. Households' perceptions of trends in sustainability for Ghodaghodi Lake resources during 1998-2007.

\begin{tabular}{|c|c|c|c|c|c|c|c|}
\hline \multirow[t]{2}{*}{ Resource } & \multirow[t]{2}{*}{ Category } & \multicolumn{3}{|c|}{ Indigenous households } & \multicolumn{3}{|c|}{ Migrant households } \\
\hline & & Increasing & Constant & Decreasing & Increasing & Constant & Decreasing \\
\hline Fuelwood & Use & $33 \dagger$ & 42 & 25 & 35 & 40 & 25 \\
\hline Fodder & Use & 42 & 40 & 18 & 44 & 37 & 19 \\
\hline Fish & Use & 38 & 42 & 20 & 34 & 40 & 26 \\
\hline Singar & Use & 61 & 25 & 14 & 62 & 30 & 8 \\
\hline Sal leaf & Use & 50 & 38 & 12 & 60 & 29 & 11 \\
\hline Vegetation around the lake & $\begin{array}{l}\text { Condition/ } \\
\text { stock }\end{array}$ & 7 & 42 & 51 & 19 & 33 & 48 \\
\hline $\begin{array}{l}\text { Wildlife, including } \\
\text { mammals, reptiles, and } \\
\text { amphibians }\end{array}$ & $\begin{array}{l}\text { Condition/ } \\
\text { stock }\end{array}$ & 7 & 40 & 53 & 10 & 33 & 57 \\
\hline Birds & $\begin{array}{l}\text { Condition/ } \\
\text { stock }\end{array}$ & 17 & 37 & 46 & 17 & 38 & 45 \\
\hline $\begin{array}{l}\text { Landslide and erosion } \\
\text { around the lake }\end{array}$ & Condition & 68 & 28 & 4 & 56 & 34 & 10 \\
\hline Sources of lake water & Condition & 14 & 58 & 28 & 9 & 67 & 24 \\
\hline Water level of lake & Condition & 23 & 58 & 19 & 16 & 66 & 18 \\
\hline
\end{tabular}

$\dagger$ Values are percentage of households.

of $\$ 35 /$ household and nearly half the average monthly cash income from all other income sources. Dahdouh-Guebas et al. (2006) also reported the use of multiple lake resources by households depending on the wetlands at East Godavari Delta, India.

\section{Lake resource sustainability trends}

The sampled households were asked to express their perceptions of general trends in the uses and condition/stock of specific Ghodaghodi Lake resources over the preceding 10-yr period from 1998 to 2007 (Table 4). Three options for the indication of trends were given to the respondents: increasing, constant, and decreasing, and respondents were free to choose an option on the basis of their own understanding.

The conditions of the wetland resources, including fuelwood and fish, neither increased nor decreased sharply during the last ten years, whereas fodder availability increased slightly. The majority of the indigenous and migrant households were convinced of an increase in lotus leaf, snail, and tortoise available at the complex during the same period. In contrast, both ethnic groups stated that mammals, reptiles, amphibians, and resident and migratory birds had decreased, which corroborates the trend reported by IUCN (1998). Direct human impacts such as landslides and erosion were found to have increased, resulting in the degradation of vegetation stock and condition, confirming the information obtained during FGD. These results are consistent with the findings of Wondie (2010), who reports intense socioeconomic activities and poor management practices as the main causes of degraded wetland ecological status in the Lake Tana region of Ethiopia. Iftekar and Takama (2008) provide a similar observation regarding the Nijhum Dwip Island of Bangladesh, where $>80 \%$ of the population perceived that the degraded condition of the mangrove wetland ecosystem was due to overexploitation. At GLC, both ethnic populations thought there was no difference in the state of water quality and availability and lake water levels despite the ecological degradation. Overall, both the indigenous and migrant communities had similar perceptions of each of the goods and services provided by the GLC.
Socioeconomic factors that affect wetland resource extraction

Socioeconomic variables that affect the extraction of wetland resources were identified. The income that was derived from the use or sale of wetland resources was considered as an indicator of resource extraction. The descriptive statistics of the variables that were used in the OLS regression analysis are presented in Table 2. The results of regression analysis for determining wetland income from the various socioeconomic variables are presented in Table 5. The $F$-ratio that was used to determine the model's overall goodness of fit was highly significant.

Table 5. Determinants of wetland-based income. Model $R^{2}=$ 0.265 , adjusted $R^{2}=0.222$. See Table 2 for description of variables.

\begin{tabular}{lccc}
\hline \hline Variable & Coefficient & Standard error & $t$-ratio \\
\hline Constant & $2694.15^{*}$ & 1103.81 & 2.44 \\
HHS & $239.19^{* *}$ & 45.94 & 5.21 \\
EDU & 184.85 & 330.78 & 0.56 \\
OHSM & $-664.59^{*}$ & 314.08 & -2.05 \\
DIST & 7.06 & 6.42 & 1.10 \\
WORK & $-1051.35^{*}$ & 477.05 & -2.20 \\
AGE & $26.49^{*}$ & 13.33 & 1.99 \\
LAND & $20.39^{*}$ & 8.86 & 2.30 \\
\hline
\end{tabular}

$* P<0.05,{ }^{* *} P<0.01$.

Wetland income was significantly influenced by household size, outstay from the house, age, and the involvement of household members in an established lake conservation organization. Family size positively and significantly affected the income that was earned from the lake resources. One additional family member increased the income from lake resources by NPR 239/yr (\$3.4/ yr USD). This increase corresponded with an increasing number of people to harvest lake resources. Outstay of the head of household negatively and significantly affected wetland income. Outstay of household members reduced the quantity of resources that were needed for the family. In addition, apart from the 
household head, other household members generally made few decisions regarding resource collection. Total agricultural land area was positively (against our hypothesis) and significantly related to wetland income. Farmers with larger holdings received more benefits from the lake than those with smaller holdings. This is because households with more land also have more domestic livestock, which means greater requirements for natural resources such as fuelwood, and fodder. The involvement of household members in organizations was negatively and significantly correlated with wetland income. Households with members that were involved with conservation organizations extracted fewer resources because they were environmentally more aware than those who were not involved. However, it is possible that people who were better off and less dependent on wetland resources for their livelihood were more involved with conservation organizations. The age of respondents positively and significantly affected the household wetland income. Respondents that were older extracted more resources and received more income from the wetland. This result occurred because mature people are more familiar with the availability, season, advantages, and use of the lake resources than are younger people. However, neither the education of the respondent nor the walking distance of the household from the lake significantly affected wetland income.

\section{Views of local lake resource users}

Attempts were made to gather the views of the local people on Ghodaghodi Lake during FGD. It was anticipated that possible solutions would be well understood by individuals who had longterm experience with the issues and consequences of GLC resource use.

More than 50 ideas were gathered from the participants in the three VDC-level FGD. These ideas were refined to make them more concise by combining similar ideas. The main purpose of this exercise was to draw recommendations that were applicable to the study area and fulfilled the aspiration of the local people who might be directly affected by future interventions. Three major concerns or ideas evolved from this exercise.

The first idea is the adoption of a community forestry model in the lake complex. Along with community forestry, the participants believed that the management ownership is legally handed to the forest user group (FUG) of the lake complex. Currently, it is under government jurisdiction and is designated as a Ramsar Site. A lake management steering committee is in place, with the tradition of designing and implementing programs in a top-down approach without consultation with local resource users. If transferred into a community forestry model, a strong FUG would be formed, taking into account the poor and disadvantaged households of the lake area that truly depend on the complex for fuelwood, fodder, timber, and other lake resources. Under the same FUG, different sub-committees could be formed to take care of different aspects of the lake complex such as forest, wildlife, and lake resources. The FUG would be entitled to develop, conserve, use, and manage the forest, and to sell and distribute resources by independently fixing the price in the market. Thus, this community forestry model would conserve the resources, facilitating the sustainable harvest of the forest and lake resources through a strong participatory annual management plan benefiting the target population. Pokhrel and Shah (2008) report a significant role of community forest groups in western
Nepal in the conservation of both floral and faunal resources, with $>93 \%$ of the local people agreeing that they have seen increased numbers of plant and wildlife species after the establishment of the FUG in the area.

The second idea is the promotion of forest and lake resourcebased enterprise as an alternative livelihood strategy for the local people. They perceived that as the population increased, so did the dependency on lake resources. The lack of alternative livelihood options means overexploitation of the resources. The lake complex could be a sustainable resource base for providing raw materials to such enterprises. It has been widely practiced in Nepal in community forests (Subedi et al. 2004, Albano et al. 2008) and could be replicated in the wetland context. The development of forest and lake resource-based nontimber forest products enterprises is possible. For example, sal leaf can be used to prepare sal leaf plate, which is in good demand for religious functions across the country. Sal seed can be used for oil extraction and used for medicinal purposes. The rhizome and leaf of lotus have medicinal value for the treatment of fever, diarrhea, and mushroom poisoning. The abundant availability of thatch grass in the complex can be used for making ropes, mats, and other household articles. Apart from these, the complex has a diverse vegetation composition that contains numerous plant species with medicinal value that have not yet been investigated.

The third idea is the introduction of ecotourism in the complex to diversify the economic opportunities of the local people and reduce their direct dependency on the lake resources. The indigenous Tharu culture, rich biodiversity, and strategic location of the lake complex between two national parks, Bardiya and Suklaphanta, could facilitate the publicity and attraction for tourism development. Basic tourist infrastructure would be needed, such as lodges, cafés, and walking trails inside the complex to view wildlife and natural scenery. The requirement of sufficient tourist guides would provide direct employment opportunities to local youth. Hussain et al. (2012) estimated a \$5 million (USD) contribution from the tourism sector in Kaziranga National Park, India during 2006-2007 of which \$3.27 million was received by various stakeholders, including the local people.

\section{Lessons learned and study limitations}

This study shows that although the residents of villages nearby GLC depend on the consumptive use of lake resources, their aspirations are for nonconsumptive use of the lake resources such as for tourism. However, to develop tourism in the area, the wetland resources need to be maintained and conserved properly, which the local people may not have the expertise to undertake. This provides a lesson that although local community participation is the key to the conservation of the lake resources, they also need support from outside agencies, initially to support their livelihoods through alternative income sources. Such support can help to create awareness among the local people and enable a smooth transition from consumptive to nonconsumptive use without compromising the sustainability of the wetland resources. However, outside support for conservation of the wetlands should not interfere in local decision making for resource conservation. The GLC resources are contributing a significant amount to the gross income of the households. We also found that there is religious sentiment associated with GLC. This shows a clear linkage between social and ecological systems, 
as advocated by Olsson et al. (2004). Therefore, its conservation is necessary through improved social transformation that helps sustainable conservation and improved livelihood. Adoption of a community-based conservation approach, along with alternative livelihood strategies, justifies the sustainability of resource use without its degradation, which has been successful in Bangladesh (Thompson and Choudhury 2007). These lessons are valid not only for Nepal, but are equally applicable to all developing countries that are struggling to manage and conserve lake resources.

Finally, a few limitations of this study should be noted. The study had a limited sample size, focusing mainly on the households residing near the lake and considering direct wetland use values; therefore, our findings should be interpreted with caution. We also only investigated a small number of tangible wetland resources and excluded the valuation of intangible resources such as cultural, tourism, biodiversity, and climate mitigation. Future studies should take these areas into consideration so that a holistic picture of the wetland resources can be obtained to formulate better conservation and livelihood policies.

\section{CONCLUSIONS AND RECOMMENDATIONS}

Wetland resources contribute significantly to the household economy of people living near the GLC. Approximately $65 \%$ of households from adjoining VDCs depend on the lake for either their own consumption or the sale of such resources for money to buy food. Fuelwood, fodder, fish, singar, and sal leaf were the major wetland resources being extracted. Wetland resource extraction was equivalent to an annual average income of NPR 4379 (\$63 USD) per household. The economic value of wetland resources that a household collects was equivalent to $12.4 \%$ of its total gross income. Multiple resource extractions from the lake were evident, especially for fuelwood, fish, and lotus leaf. Household size, age, and land holdings increased the dependency of households on wetland resources. In contrast, involvement with local conservation organizations reduced this dependency. Although most of the households near the lake depended on the wetland resources for their livelihoods, only $18 \%$ were involved in conservation activities. Fuelwood was the most extracted wetland resource, with $95 \%$ of households involved in the collection of fuelwood from the lake complex. No differences in perception were observed between indigenous and migrant people regarding resource sustainability trends over the last ten years. Overall, both the ethnic populations were satisfied with the conservation activities being undertaken in the GLC.

This study leads us to three recommendations. First, the management system of the GLC could be transformed into a community forest management model with integration up to the catchment level, a form of community-based conservation with options for the FUG to develop enterprises and ecotourism to reduce resource dependency. Second, because fuelwood extraction from the lake complex for cooking-energy purposes was very high (nearly $95 \%$ of households), alternative strategies in the form of biogas and improved cooking stoves are feasible to reduce the degradation of vegetative cover. Finally, social and ecological systems are linked, so more awareness programs are needed, focusing at all levels of community members in the study area, as people's participation in conservation activities is comparatively low.
Responses to this article can be read online at: http://www.ecologyandsociety.org/issues/responses. $\mathrm{php} / 7172$

\section{LITERATURE CITED}

Abbot, P. G., and A. Hailu. 2001. Sustainable wetland management: lessons from Illubabor Zone. Policy Briefing Notes, Issue 3. Ethio-Wetlands and Natural Resources Association, Jimma, Ethiopia. [online] URL: http://www.wetlandaction.org/ pdf/pbn3.pdf.

Adekola, O., S. Morardet, R. de Groot, and F. Grelot. 2012. Contribution of provisioning services of the Ga-Mampa wetland, South Africa, to local livelihoods. International Journal of Biodiversity Science, Ecosystem Services and Management 8 (3):248-264. http://dx.doi.org/10.1080/21513732.2012.671191

Adhikari, B. 2003. Property rights and natural resources: socioeconomic heterogeneity and distributional implications of common property resource management. SANDEE Working Paper 1-03. SANDEE, Kathmandu, Nepal. [online] URL: http://www. sandeeonline.com/uploads/documents/publication/783_PUB bhim_report. pdf.

Albano, A., B. H. Pandit, C. Kumar, and B. Belcher. 2008. Developing community-based forest enterprises in Nepal. Forest Livelihood Briefs 10. Center for International Forestry Research, Bogor, Indonesia. [online] URL: http://www.cifor.org/publications/ pdf_files/livebrief/livebrief0804.pdf.

Andrade, G. S. M., and J. R. Rhodes. 2012. Protected areas and local communities: an inevitable partnership toward successful conservation strategies? Ecology and Society 17(4): 14. http://dx. doi.org/10.5751/ES-05216-170414

Andrianandrasana, H. T., J. Randriamahefasoa, J. Durbin, R. E. Lewis, and J. H. Ratsimbazafy. 2005. Participatory ecological monitoring of the Alaotra wetlands in Madagascar. Biodiversity and Conservation 14(11):2757-2774. http://dx.doi.org/10.1007/ s10531-005-8413-y

Bajracharya, S. B., P. A. Furley, and A. C. Newton. 2006. Impacts of community-based conservation on local communities in the Annapurna Conservation Area, Nepal. Biodiversity and Conservation 15(8):2765-2786. http://dx.doi.org/10.1007/s10531-005-1343$\underline{\mathrm{x}}$

Bam, Y. B. 2002. Conservation and sustainable use of Ghodaghodi Lake system. Action Plan. IUCN Nepal, Kathmandu, Nepal.

Baral, N., and J. T. Heinen. 2007. Decentralization and people's participation in conservation: a comparative study from the Western Terai of Nepal. International Journal of Sustainable Development and World Ecology 14(5):520-531. http://dx.doi. org/10.1080/13504500709469751

Bosma, R., A. S. Sidik, P. van Zwieten, A. Aditya, and L. Visser. 2012. Challenges of a transition to a sustainably managed shrimp culture agro-ecosystem in the Mahakam Delta, East Kalimantan, Indonesia. Wetlands Ecology and Management 20(2):89-99. http://dx.doi.org/10.1007/s11273-011-9244-0 
CBS [Central Bureau of Statistics]. 1991. National population and housing census 1991 report. CBS, National Planning Commission Secretariat, Government of Nepal, Kathmandu, Nepal.

CBS [Central Bureau of Statistics]. 2001. National population and housing census 2001 report. CBS, National Planning Commission Secretariat, Government of Nepal, Kathmandu, Nepal.

CBS [Central Bureau of Statistics]. 2011. National population and housing census 2011 report. CBS, National Planning Commission Secretariat, Government of Nepal, Kathmandu, Nepal.

Chhetri, B. B. K. 2005. Community forestry program in the hills of Nepal: determinants of user participation and household dependency. Thesis. Norwegian University of Life Science, Ås, Norway. [online] URL: http://www.forestrynepal.org/images/ MSc BBKhanal.pdf.

Chun, M. H., W. N. A. Sulaiman, and M. A. A. Samah. 2012. A case study on public participation for the conservation of a tropical urban river. Polish Journal of Environmental Studies 21 (4):821-829.

Convention on Wetlands. 1971. Convention on wetlands of international importance especially as waterfowl habitat 1971. Adopted by the International Conference on the Wetlands and Waterfowl at Ramsar, Iran. UNESCO, Paris, France.

Dahdouh-Guebas, F., S. Collin, D. Lo Seen, P. Rönnbäck, D. Depommier, T. Ravishankar, and N. Koedam. 2006. Analysing ethnobotanical and fishery-related importance of mangroves of the East-Godavari Delta (Andhra Pradesh, India) for conservation and management purposes. Journal of Ethnobiology and Ethnomedicine 2(1): 24. http://dx.doi.org/10.1186/1746-4269-2-24

Diegues, A. S. 1991. The role of cultural diversity and communal participation in wetland management in Brazil. Landscape and Urban Planning 20(1-3):61-66. http://dx.doi.org/10.1016/0169-2046 (91)90092-Z

Diouf, A. M. 2002. Djoudj National Park and its periphery: an experiment in wetland co-management. Pages 13-17 in M. Gawler, editor. Strategies for wise use of wetlands: best practices in participatory management. Wetlands International/IUCN/WWF Publication 56. Wetlands International, Wageningen, The Netherlands. [online] URL: http://www.wetlands.org/LinkClick. aspx?fileticket $=18 \mathrm{H} 67 \mathrm{olK} 100 \% 3 \mathrm{~d} \&$ tabid $=56$.

Gurung, S., S. Sharma, and C. M. Sharma. 2009. A brief review on limnological status of high altitude lakes in Nepal. Journal of Wetlands Ecology 3:12-22. http://dx.doi.org/10.3126/jowe. $\underline{\mathrm{v} 3 \mathrm{i} 0.2387}$

Halima, K. H., and P. K. Munishi. 2009. Contribution of wetlands to household income and food security in the Nyumba Ya Mungu wetland system, northern Tanzania. Tanzania Journal of Forestry and Nature Conservation 79(2):99-108.

Hussain, S. A., S. C. Barthwal, R. Badola, S. M. T. Rahman, A. Rastogi, C. Tuboi, and A. K. Bhardwaj. 2012. An analysis of livelihood linkages of tourism in Kaziranga National Park, a natural world heritage site in India. Parks 18(2):33-43. http://dx. doi.org/10.2305/IUCN.CH.2012.PARKS-18-2.SAH.en

Iftekhar, M. S., and T. Takama. 2008. Perceptions of biodiversity, environmental services, and conservation of planted mangroves: a case study on Nijhum Dwip Island, Bangladesh. Wetlands Ecology and Management 16(2):119-137. http://dx.doi.org/10.1007/ $\underline{\text { s11273-007-9060-8 }}$

Islam, K. M. B. 2011. Community based water resource management - some regional experiences. Pages 3-12 in C. K. Jain, K. M. B. Islam, and S. K. Sharma, editors. Community based water resources management in North East India: lessons from a global context. Allied, New Delhi, India.

IUCN [International Union for Conservation of Nature]. 1998. The Ghodaghodi Tal conservation area: a community centered management plan. IUCN Nepal, Kathmandu, Nepal.

Jha, S. 2008. Status and conservation of lowland Terai wetlands in Nepal. Our Nature 6(1):67-77. http://dx.doi.org/10.3126/on. $\underline{\mathrm{v} 6 \mathrm{i} 1.1657}$

Kafle, M. R. 2008. Contribution of community forestry to user's household income: a financial analysis. Thesis. Tribhuwan University, Pokhara, Nepal. [online] URL: http://www. forestrynepal.org/images/thesis/MSc_MRKafle.pdf.

Khanal, S. 2009. Change assessment of forest cover in Ghodaghodi Lake area in Kailali district of Nepal. Banko Janakari 19(2):15-19. http://dx.doi.org/10.3126/banko.v19i2.2980

Mehta, J. N., and J. T. Heinen. 2001. Does community-based conservation shape favorable attitudes among locals? An empirical study from Nepal. Environmental Management 28 (2):165-177. http://dx.doi.org/10.1007/s002670010215

Millennium Ecosystem Assessment. 2005. Ecosystems and human well-being: wetlands and water synthesis. World Resources Institute, Washington, D.C., USA. [online] URL: http://www. unep.org/maweb/documents/document.358.aspx.pdf.

Niraula, R. 2012. Evaluation of the limnological status of Beeshazar Lake, a Ramsar Site in central Nepal. Journal of Water Resource and Protection 4:256-263. http://dx.doi.org/10.4236/ jwarp.2012.45028

O'Connell, M. J. 2003. Detecting, measuring and reversing changes to wetlands. Wetlands Ecology and Management 11 (6):397-401. http://dx.doi.org/10.1023/B:WETL.0000007191.77103.53

Olsson, P., C. Folke, and T. Hahn. 2004. Social-ecological transformation for ecosystem management: the development of adaptive co-management of a wetland landscape in southern Sweden. Ecology and Society 9(4): 2. [online] URL: http://www. ecologyandsociety.org/vol9/iss4/art2/.

Opio, A., J. K. Lukale, I. S. Masaba, and C. Oryema. 2011. Socioeconomic benefits and pollution levels of water resources, Pece wetland, Gulu Municipality - Uganda. African Journal of Environmental Science and Technology 5(7):535-544. http://dx. doi.org/10.5897/AJEST10.205

Pokhrel, G. K., and K. B. Shah. 2008. Role of community forests in faunal diversity conservation: a case study of community forests within Satbariya Range Post of Dang District. Nepal Journal of Science and Technology 9:111-117. http://dx.doi. org/10.3126/njst.v9i0.3174

Rahman, M. M., and A. Begum. 2011. Implication of livelihood diversification on wetland resources conservation: a case from 
Bangladesh. Journal of Wetlands Ecology 5:59-65. http://dx.doi. org/10.3126/jowe.v5i0.4905

Rahman, M., M. F. Tazim, S. C. Dey, A. K. M. S. Azam, and M. R. Islam. 2012. Alternative livelihood options of fishermen of Nijhum Dwip under Hatiya Upazila of Noakhali District in Bangladesh. Asian Journal of Rural Development 2(2):24-31. http://dx.doi.org/10.3923/ajrd.2012.24.31

Regmi, B. R., G. Kafle, A. Adhikari, A. Subedi, R. Suwal, and I. Paudel. 2009. Towards an innovative approach to integrated wetland management in Rupa Lake area of Nepal. Journal of Geography and Regional Planning 2(4):80-85.

Sah, J. P., and J. T. Heinen. 2001. Wetland resource use and conservation attitudes among indigenous and migrant peoples in Ghodaghodi Lake area, Nepal. Environmental Conservation 28 (4):345-356. http://dx.doi.org/10.1017/S0376892901000376

Siwakoti, M., and J. B. Karki. 2009. Conservation status of Ramsar sites of Nepal Tarai: an overview. Botanica Orientalis: Journal of Plant Science 6:76-84. http://dx.doi.org/10.3126/botor. $\underline{\mathrm{v} 6 \mathrm{i} 0.2914}$

Subedi, B. P., H. R. Ojha, K. Nicholson, and S. B. Binayee. 2004. Community based forest enterprises in Nepal: case studies, lessons and implications. ANSAB and SNV/Nepal, Kathmandu, Nepal. [online] URL: http://www.ansab.org/wp-content/uploads/2002/12/ Nepal-CBFE-Case-Studies.pdf.

Thapa, I., and B. R. Dahal. 2009. Sustainable wetland management for wildlife and people at Koshi Tappu Wildlife Reserve. Banko Janakari Special Issue:36-39. http://dx.doi. org/10.3126/banko.v19i3.2210

Thapa, J. B., and T. B. Saund. 2012. Water quality parameters and bird diversity in Jagdishpur Reservoir, Nepal. Nepal Journal of Science and Technology 13(1):143-155. http://dx.doi. org/10.3126/njst.v13i1.7453

Thompson, P., and S. N. Choudhury. 2007. Experiences in wetland co-management - the MACH project. Conference Paper 8. World Fish Center, Penang, Malaysia. [online] URL: http://www. worldfishcenter.org/resource_centre/WF_37452.pdf.

Trisurat, Y. 2006. Community-based wetland management in northern Thailand. International Journal of Environmental, Cultural, Economic and Social Sustainability 2(1):49-62.

Turyahabwe, N., W. Kakura, M. Tweheyo, and D. M. Tumusiime. 2013. Contribution of wetland resources to household food security in Uganda. Agriculture and Food Security 2(1): 5. http:// dx.doi.org/10.1186/2048-7010-2-5

Williams, W. D. 2002. Community participation in conserving and managing inland waters. Aquatic Conservation: Marine and Freshwater Ecosystems 12(3):315-326. http://dx.doi.org/10.1002/ aqc. 510

Wondie, A. 2010. Improving management of shoreline and riparian wetland ecosystems: the case of Lake Tana catchment. Ecohydrology and Hydrobiology 10(2-4):123-131. http://dx.doi. org/10.2478/v10104-011-0017-4

Wood, A., A. Hailu, P. Abbot, and A. Dixon. 2002. Sustainable management of wetlands in Ethiopia: local knowledge versus government policy. Pages 81-88 in M. Gawler, editor. Strategies for wise use of wetlands: best practices in participatory management. Wetlands International/IUCN/WWF Publication 56. Wetlands International, Wageningen, The Netherlands. [online] URL: http://www.wetlands.org/LinkClick.aspx? fileticket $=18 \mathrm{H} 67 \mathrm{olKloo} \% 3 \mathrm{~d} \&$ tabid $=56$.

Xie, Z., X. Xu, and L. Yan. 2009. Analyzing qualitative and quantitative changes in coastal wetland associated to the effects of natural and anthropogenic factors in a part of Tianjin, China. Estuarine, Coastal and Shelf Science 86(3):379-386. http://dx.doi. org/10.1016/j.ecss.2009.03.040 